PSYCHOLOGIA ROZWOJOWA, $2020 *$ tom 25, nr 1, s. 31-48

doi:10.4467/20843879PR.20.002.11999

www.ejournals.eu/Psychologia-Rozwojowa

DANUTA BORECKA-BIERNAT (D) orcid.org/0000-0003-1401-9821

Instytut Psychologii, Uniwersytet Wrocławski

Institute of Psychology, University of Wrocław e-mail: danuta.borecka-biernat@uwr.edu.pl

\title{
Adolescent Coping Strategies in Social Conflict in Relation to Self-Esteem and Cognitive Appraisal of a Conflict
}

\begin{abstract}
The aim of the research was to assess the role of self-esteem and cognitive appraisal of a conflict in generating destructive and constructive strategies of coping used by adolescents in social conflict situations. The following research tools have been used in the research: the SelfEsteem Scale (SES) developed by M. Rosenberg, adapted by M. Łaguna, K. Lachowicz-Tabaczek, and I. Dzwonkowska; the Stress Appraisal Questionnaire (SAQ) (Polish: KOS - Kwestionariusz Oceny Stresu) by D. Włodarczyk and K. Wrześniewski; as well as the Questionnaire for the study of adolescents'coping strategies employed in social conflict situations (Polish: KSMK - Kwestionariusz strategii radzenia sobie młodzieży w sytuacji konfliktu społecznego) developed by D. Borecka-Biernat. The empirical research was carried out in middle schools (Polish: gimnazjum). The research involved 893 adolescents ( 468 girls and 425 boys) aged 13-15. Analysis of research results indicates that in the case of adolescents, lower assessment of one's capacities and the appraisal of conflict in terms of threat or harm/loss, generally coincides with the tendency to react destructively when faced with a conflict. The research has also indicated that an adolescent with higher self-esteem, when involved in a conflict that is not assessed as threatening, implements a constructive strategy to cope with the situation.
\end{abstract}

Keywords: adolescents, self-esteem, cognitive appraisal, coping strategies, a social conflict situation

Słowa kluczowe: młodzież, samoocena, ocena poznawcza, strategie radzenia sobie, sytuacja konfliktu społecznego

\section{ADOLESCENTS IN A SOCIAL CONFLICT SITUATION}

Difficult situations are not exceptional in the life of a human being. On the contrary, they accompany everyone since early childhood. Therefore, the knowledge of activities undertaken by an individual to cope with difficult situations and the factors conditioning them is essential. In psychology, "a difficult situation" is strictly associated with the activities performed by an individual while adjusting hers or his attitude to the environment (Tomaszewski, 1984). Difficult situations are not a homogenous class of situations, but a rather internally diverse one. An important group of difficult situations are those social situations that threaten the following: the values significant to a given person, the fulfilment of one's needs, as well as the realisation of one's aspirations of a social nature (Tyszkowa, 1986). Among difficult situations of social interaction type, one may distinguish those social conflict situations, where the aspirations of an individual are contradictory or incompatible with the aspirations of other people and the realisation of the individual aspirations is threatened. The word conflict originates from the Latin noun confligere, conflictatio, meaning: 
to strike together, a dispute, discussion, fight or a collision of two or more processes, powers specific to living creatures. Conflicts arise from everyday contacts, either between individuals or between an individual and a group, as a result of occurring incongruities, disagreements or discrepancies concerning goals to be achieved by the parties of the conflict, the views, attitudes, interests and values, or the motivation of one's endeavours or desires (Balawajder, 2010). All these create situations of a difficult nature for an individual, as they impede one's activities, decreasing the probability of achieving a set goal.

Adolescence is an important period in the life of every human being, since it is regarded as a transition between childhood and adulthood. It is a time of numerous developmental changes, that have their counterpart in the changes in appearance connected with biological development, which occurs in a young person between the age of 13 and 15 (Harwas-Napierała, Trempała, 2000). However, this period, above all, is a time of discovering one's potential and of directing self-development - creating the me, the system of values and worldviews - all of which is accompanied by the irresistible need to achieve subjectively perceived freedom. The gradual "growing into" the adult society begins in this period. One may also notice changes in social relationships with both adults and peers (Czerwińska-Jasiewicz, 2003). Young people broaden their social world, they gain more freedom and independence while making decisions in various areas of behaviour, which increase the likelihood of the occurrence of a conflict. In social contacts, there appear conflicts with teachers, quarrels with schoolmates or sweethearts, as well as arguments with one or both parents and other family members (Kobus, Reyes, 2000; Lohman, Jarvis, 2000; Smetana, Daddis, 2002; Różańska-Kowal, 2004; Polak, 2010; Gurba, 2013). The most conflicting areas in a student-teacher relationship are school grades, tactless behaviour of a teacher as well as the commanding pressure and the inflexibility of requirements. As for peer conflicts, here one may distinguish: provocation, betrayal, indiscretion, as well as competition with regard to school grades, popularity among the opposite sex, ruling in the class and sport prestige. The majority of problems seen in the mutual understanding between parents and children arise from the change in the attitude manifested by adolescents towards their parents. Young people are less open to their parents, who, in turn, often fail to cope with the growing autonomy of their maturing children by trying to impose some limits. Numerous conflicts with parents concern everyday situations - differences in tastes and opinions, for instance - connected with school performance, clothes, music, television watching, using the computer, spending free time or late homecomings.

\section{ADOLESCENTS' COPING STRATEGIES IN A SOCIAL CONFLICT SITUATION}

Social conflict situations, included in the category of difficult situations in social interactions, accompany people in every period of their lives. They should be treated as a normal aspect of a human life. The statement that a conflict is a part of human existence and nature seems to be right. Not less important than the fact that conflicts are an inevitable element of social relationship is learning how to solve them with as little damage as possible to oneself and other people, and with benefit for both sides of a conflict. When growing up, young people follow various, often contradictory pursuits and they need to cope with incoherent social expectations directed towards them. A difficult situation encourages a young person to undertake activities directed to restore the balance between the requirements and the abilities, and/or to improve the emotional state. The activity, undertaken by a young person in a difficult situation, is viewed in a particular situational context as a coping strategy used in a given difficult situation (Heszen-Niejodek, 2002). As was mentioned earlier, the school environment is particularly stressful for adolescents, especially conflict situations with teachers, schoolmates or dates, as well as arguments with one or both parents and other members of a family. Therefore, the way adolescents cope with conflict situations 
occurring at school, in peer relationships or at home, is worth considering. Numerous research as well as simple observation indicate that adolescents use a wide range of coping strategies in conflict situations happening at school, in peer relationships or at home. Among them, one may distinguish destructive and constructive strategies (Donaldson, Prinstein, Danovsky, Spirito, 2000; Williams, McGillicuddy-DeLisi, 2000; Deutsch, 2005; Pisula, Sikora, 2008; Kłusek-Wojciszke, 2009; Balawajder, 2010; Wilmot, Hocker, 2011; Borecka-Biernat, 2012). The discipline imposed by school and parents, not enough adolescent independence, lack of understanding for the youth interests, lead to quarrels, fights and rebellion. Some adolescents, while faced with a conflict at school, in relationship with peers or at home, make use of a destructive strategy by responding aggressively to a conflict, avoiding active participation in the conflict by becoming engaged in other stressless forms of activity or by giving in to the conflict. Nonetheless, there are young people who cope well in a social conflict situation, treating it as a challenge, which helps to mobilise their resources to overcome obstacles preventing the realisation of their needs.

\section{COGNITIVE DETERMINANTS OF COPING STRATEGIES EMPLOYED BY ADOLESCENTS IN A SOCIAL CONFLICT SITUATION}

Considerations so far indicate that a social conflict situation is connected with coping strategies used in a particular situational context, aiming at restoring the balance between the requirements and the adaptive possibilities, avoiding or lowering tensions, losses, and unfavourable effects. Both the research results and observations point to individually diversified reactions to obstacles and the defence against excessive emotional tension among young people (Pisula, Sikora, 2008). According to Maria Tyszkowa (1986) in the psychological mechanism of human behaviour in difficult situations, a particular role is played by basic cognitive structures of personality: the image of the world (the structure the world) as well as the image of oneself (the structure me). One's perception of the world, their attitudes and expectations towards themselves, other people, tasks and results of one's activity, define the cognitive and emotional perception and interpretation of a difficult situation, which in turn, influence the behaviour in such a situation.

A range of conceptions and images about oneself as well as expectations towards oneself - in other words, the structure me - play a significant role in human behaviour seen in difficult situations (Kulas, 1986). Information pertaining to oneself, traits constituting the knowledge about oneself are the premise to assess one's capabilities in difficult situations (Tyszkowa, 1986). Self-esteem is inseparably connected with the concept of the self, it is the appraisive-evaluative component of the system of a person's knowledge about me. It is usually defined as a positive or a negative attitude towards oneself(Gregg, 2003). High self-esteem in Morris Rosenberg's (1965) view is equal to the conviction that one is a good and a valuable person, whereas low self-esteem is equated with dissatisfaction with oneself or the rejection of one's me.

Research results obtained by Danuta Borecka-Biernat (2006), Pan Brent Donnellan, Kali Trzesniewski, Richard Robins, Terrie E. Moffitt, and Avshalom Caspi (2005), Anna Brytek (2007), and Nina Ogińska-Bulik (2001), indicated that the unfavourable role in behaviour of a young person in difficult situations is played by low (adequate or inadequate) and high (inadequate) self-esteem. When an individual faces difficulties of a situation, inadequate self-esteem leads to the increase of the feeling of a personal threat, negative emotions as well as the disorganisation of behaviour. In case of low self-esteem, the tendency to resign from achieving the goal, refraining from activities and withdrawal from social interaction may appear. A man who appraises oneself low, has a tendency to overrate difficulties and is rather ready to surrender to them than struggle with them. People who appraise their own abilities and intellectual capacities as low, when confronted with a difference of views, hardly ever start a discussion. They 
do not defend their standpoint decisively, they often step aside by the power of their partner's arguments, or give in to persuasion and accept the opinions expressed by the participants of the interaction. Besides, low self-esteem, low appraisal of one's capacities and effectiveness of one's performance in the face of a difficult event, favour the occurrence of aggressive behaviours. It further conditions a negative attitude towards other people, which in turn, affects the distorted nature of interpersonal contacts with others, worsening the relationships with them. Michael K. Ostrowsky (2010) in an attempt to explain the occurrence of low self-esteem in aggressive people, states that this type of behaviour is a form of externalisation of one's feeling of inferiority and shame as well as blaming others for such a state, consequently leading to an attack. Speaking of high (inadequate) self-esteem, one may notice a tendency to show strong negative emotions and acting-out, aggressive reactions. People with high, almost narcissistic self-esteem have a tendency to become angry and react aggressively, especially in situations, when their self-esteem is threatened. Extremely high self-esteem and exaggerated positive selfassessment, do not favour maintaining beneficial relationships with the environment. People with such self-esteem are often conceited and too self-confident. They ignore others and do not pay attention to their opinions (Baumeister, Campbell, Krueger, Vohs, 2003; Perez, Vohs, Joiner, Thomas, 2005).

People with high (adequate) self-esteem turned out to be the least vulnerable to the disorganisation of behaviour in a difficult situation. Such self-esteem favours higher mental resistance in a difficult situation and allows to behave constructively when faced with various stressful events (Baumeister et al., 2003; Brytek, 2007; Kurtek, 2012). People with high self-esteem do not view themselves as better or more ideal. Such people know their value, trust themselves, are satisfied with their achievements. They are aware of their mistakes and limitations, however, they undertake activities to overcome a conflict. In professional literature, one may find information proving that the concept of self-esteem is interchangeably used with the concept of global self-esteem (Szpitalak, Polczyk, 2015). An interesting study on the significance of self-esteem in predicting the ways of coping in difficult situations in children aged 11-12 was carried out by Ogińska-Bulik (2001). The researcher found out that high self-esteem, especially the one connected with functioning at school and in the family, contributes to more frequent use of active strategies, treated as the most effective in the process of coping with difficult situations.

Concluding this part of considerations, it is difficult not to notice, that the appraisal of one's own capabilities plays a significant role in coping with difficult situations in social interactions, since the appraisal determines whether the estimation result of the requirements-capabilities relationship shall be in consequence of a negative or a positive nature. The faith in one's capabilities favours more effective coping with difficult situations. Everything changes when the faith in one's capabilities is rather low. Then, a little obstacle or a slight threat may cause a violent reaction. An individual may easily become strongly emotionally stimulated or unstoppably aggressive. There occurs a tendency to retreat from cooperation with others or to avoid contact with people. In a conflict, one may agree to the proposals put forward by the other side and surrender to them.

The functioning of a human being in a difficult situation depends to a large extent on the appraisal of one's position. The cognitive appraisal of a situation is an internal (hidden) process occurring in almost every sphere of an individual's functioning and it fulfils an adaptive function to the requirements of the environment. The subjects of the appraisal are the elements from the individual's environment which are significant for one's well-being and, at the same time, appraised as favourable/positive or insignificant/stressful. A particular role of cognitive appraisal is visible in difficult situations, which impede the current course of activities, threaten the person, hinder or prevent the realisation of one's needs. A stressful event may be appraised as a harm/loss (concerns the suffered damages and losses connected with important objects), as a threat (refers to similar damage that has not occurred yet and 
is anticipated), and as a challenge (indicates the possibility of taking control over a difficult situation and gaining something; Włodarczyk, Wrześniewski, 2005). Therefore, in order to find out whether a given situation is harmful, threatening or challenging to an individual, the cognitive appraisal is necessary. The same situation may be interpreted in a completely different manner by different people, depending on whether (and to what extent) the situation is subjectively appraised as a harm/loss, threat or challenge. Based on clinical observations and data taken from the literature, situational and dispositional appraisal of a stressful situation have been distinguished (Włodarczyk, Wrześniewski, 2005). The situational appraisal of stress is the aspect of the assessment which depends mainly on the current characteristics of a stressful event, whereas the dispositional appraisal of stress is understood as a permanent tendency to appraise one's relationships with the environment in a specific way.

An individual appraisal of a particular, difficult situation affects the individual's decisions concerning the possibilities to undertake an activity, eliminating the causes of a difficult situation or at least easing its results, defined as a remedial strategy (Heszen-Niejodek, 2002; Włodarczyk, Wrześniewski, 2005). Considering the criterion of the function of activities aimed at coping with a situation appraised by an individual as a challenge, threat or harm/loss, Richard Lazarus and Susan Folkman (1984) distinguished two main strategies of coping with difficult (stressful) situations; a problem-focused coping strategy and an emotion-focused coping strategy. The former involves active fighting with the difficult situation in order to overcome it. People using problem-focused coping strategies treat a difficult situation as a problem to be solved, they mobilise themselves to make an effort, look for new ways of conduct, analyse the situation in light of earlier experiences namely, they accept the challenge and directly confront the difficult situation. In this strategy, a difficult situation is often appraised as a challenge. The latter strategy involves reducing the tension and unpleasant emotions arising in response to a difficult situation. It is character- ised by adopting avoiding behaviours, such as, rejecting and denying information concerning the stressful event, as well as protecting oneself against such information by engaging in other, stressless activities.

Research carried out by Dorota DomińskaWerbel (2014) indicated that there is a connection between the types of situational appraisal (challenge, threat, harm/loss) and the preferred remedial forms used by adolescents in difficult situations of social interaction type. The author specifies the category of difficult situations by including among them social conflict situations, social pressure situations, as well as situations of social exposition, appraisal and criticism. The results of the research indicate that the determinant of a task-oriented coping strategy employed by adolescents in difficult situations is a higher tendency to the situational and dispositional appraisal of difficult situations as a challenge and a lower tendency to the dispositional appraisal of difficult situations as a harm/loss. The author, on the basis of her research, found that the source of avoidance as a coping strategy used by adolescents in difficult social situations is a higher tendency to the dispositional appraisal of difficult situations as a threat and a lower tendency to the situational appraisal of difficult situations as a challenge. The author's research indicated that adolescents using aggression as a coping strategy in difficult situations are distinguished by a higher tendency to the dispositional appraisal of difficult situations as a harm/ loss and a lower tendency to the dispositional appraisal of difficult situations as a threat and as a challenge. A similar result was obtained by Louis Chandler (1986) in his research. It turned out that people presenting higher intensity of situational and dispositional appraisal of a difficult situation as a harm/loss, show aggression, antisocial behaviours, hyperactivity or passiveaggressive behaviours.

Similar results were obtained by Elżbieta Pawłów (1997), who found out that people appraising a difficult situation as a challenge solved a problem using, mostly, realistic strategies from the level of specific detailed solutions. A person finds motivation to undertake an activity required to cope with a difficult 
situation, when they have the disposition to appraise the situation as a challenge, which assumes hope and optimism in the realisation of goals and intentions, especially because the ability to achieve the goals is based on a realistic strategy. However, the participants of the research who appraised a difficult situation as a threat, when faced with a problem, used, to a large extent, unrealistic coping mechanisms. Their whole effort was directed at lowering the unpleasant tension following a rapid release of emotions and/or activating defence mechanisms, not at finding the real solution of the problem. Pawłów’s (1997) findings correspond to the results of examination performed by Mark Anshel and Bruce Wells (2000), Kent Kowalski, Peter Crocker, and Sharleen Hoar (2005), Mario Mikulincer and Florian Victor (1995) who found that the appraisal of a situation as a threat initiates coping focused on emotions, aiming at reducing tension, and avoidance strategies. However, the appraisal of a situation as a challenge activates the search for support and the attitude directed at the solution of the problem.

The discussed research results indicate that the appraisal of a situation as a threat or harm/ loss, make an individual use destructive strategies, focused on lowering unpleasant tension and easing negative emotional states arising from a difficult situation. However, the appraisal of a situation as a challenge is tied with the use of constructive strategies directed at the solution of the problem.

\section{THE RESEARCH PROBLEM AND THE RESEARCH HYPOTHESIS}

The empirical research was focused on personality determinants of destructive (aggressive, avoiding, submissive) and constructive (task-oriented) coping strategies used by adolescents in a social conflict situation, with an emphasis put on the role of the level of one's self-esteem and the type of cognitive appraisal in a social conflict situation. The research aimed at providing answers to the following research question:

1 . What set of personality variables is related to the fact that in a social conflict situation the use of destructive and constructive coping strategies by adolescents is intensified?

This question allows to formulate the following hypothesis, the verification of which shall be performed on the basis of the analysis of the empirical research results.

H.1. Adolescents with low self-esteem and appraising a conflict situation as a threat or harm/ loss, more often use destructive strategies of coping in a social conflict situation. Whereas, adolescents with high self-esteem and apprising a conflict situation as a challenge more often activate constructive strategies of coping in a social conflict situation.

\section{THE METHODOLOGY OF THE RESEARCH}

The following methods have been used in the research:

1. The Self-Esteem Scale (SES) by Rosenberg adapted by Mariola Laguna, Kinga Lachowicz-Tabaczek, and Irena Dzwonkowska (2007) allows to calculate the level of general (global) self-esteem both in adolescents and adults. SES consists of ten diagnostic, descriptive statements concerning oneself, by means of which, the respondent performs a description of hers or his me. The person answers on a fourpoint scale. Each answer is granted from 1 to 4 points. Finally, the results range from 10 to 40 points. A high score means a high level of general (global) self-esteem. The Polish version of SES method is a reliable tool (Cronbach $\alpha$ in different research ranges from .81 to .83 ) and its theoretical validity has been confirmed.

2. The Stress Appraisal Questionnaire (SAQ; Polish: KOS - Kwestionariusz Oceny Stresu) developed by Dorota Włodarczyk and Kazimierz Wrześniewski (2010) contains 35 (including 23 diagnostic) adjectival terms assessing stressful situations. It consists of two versions, which cover the same sets of adjectival terms, but differ in terms of the instruction provided to the respondents. In Version A (the situational stress appraisal measurement) the respondents are asked to indicate a particular difficult situation that took place during the last week (in 
the described research, it was a social conflict situation). Version B (the dispositional stress appraisal measurement) contains an instruction which asks the respondents to mark, to what extent the provided adjectives comply with what they experience most often in difficult situations (in the described research, it was a social conflict situation). KOS consists of six subscales being the indicators of particular types of stress appraisal. They are: threat-state, threat-trait, harm/ loss-state, harm/loss-trait, challenge-state and challenge-trait. The subscales threats contain 10 items, the subscales challenge -6 items, and the harm/loss subscales -4 items. The questionnaire has satisfactory reliability (internal consistency coefficient Cronbach $\alpha$ for version A is .76-.90, and for version B the result is .79-.90), factor validity and criterion validity.

3. The Questionnaire to study adolescents' coping strategies employed in social conflict situations (CSCS; Polish: KSMK - Kwestionariusz strategii radzenia sobie młodzieży w sytuacji konfliktu społecznego) developed by Borecka-Biernat (2012) is intended to study coping strategies used by adolescents in a social conflict situation. It consists of a description of 33 social conflict situations. Each situation is given four behaviours describing coping with a social conflict situation: the first one refers to an aggressive coping (AG), the second - to an avoiding coping (A), the third - to a submissive coping (S), the fourth - to a task-oriented (constructive) coping in a social conflict situation (T). The results are obtained for each scale separately by summing up marked behaviours in 33 situations being part of a particular scale. The questionnaire has a good reliability (internal consistency coefficient Cronbach $\alpha$ for the scale AG, $\mathrm{S}$ and $\mathrm{T}$ is .73, and for the scale $\mathrm{A}$ it is .694) and diagnostic validity.

\section{THE PARTICIPANTS OF THE RESEARCH}

The respondent group included 468 girls and 425 boys aged $13-15$. In total, 893 persons participated in the conducted research. The respondents were students of the first, second and third grades of junior high schools. The participation was voluntary and anonymous. Schools were chosen randomly, however not all selected schools agreed to participate in the research, therefore a few other schools, which were not randomly selected, were asked for this kind of cooperation. The research was carried out in accordance with the rules of psychological scientific research.

\section{RESEARCH RESULTS}

In order to determine what set of personality variables anticipates the level of coping strategies used by adolescents in a social conflict situation, it was decided to use regression in hierarchical mode with the use of backward elimination method (criterion: likelihood of $\mathrm{F}$ - deletion $\geq .100$ ). The method involves introducing all potential variables to the model, followed by successive deletion of insignificant variables, and repeating this process until the final image is obtained (Bedyńska, Książek, 2012). The results on the four scales of the CSCS questionnaire; aggressive coping in a social conflict situation (AG), avoiding coping in a social conflict situation (A), submissive coping in a social conflict situation (S), and task-oriented (constructive) coping in a social conflict situation (T) have been adopted as dependent variables. The set of independent variables includes the results on one scale (self-esteem) of the SES questionnaire and the results on the following six scales (threat-state and threat-trait, harm/loss-state and harm/loss-trait and challenge-state and challenge-trait) of the KOS questionnaire. The results are shown in Tables 1-4.

The first analysis was carried out based on the results for the whole group of the adolescents in question, regardless of sex. As Table 1 shows, one variable had a significant influence on the strategy of aggressive coping used by adolescents in a social conflict situation; the situational appraisal of a conflict as a threat. The coefficient of multiple correlation is $\mathrm{R}=.11$ and it indicates that the linear correlation between the strategy of aggressive coping used by adolescents in a social conflict situation and total 
Table 1. Stepwise multiple regression for the result of the Aggression (AG) scale of the CSCS questionnaire against self-esteem of the Self-Esteem Scale (SES) and cognitive appraisal of the Stress Appraisal Questionnaire (SAQ; in Polish: KOS) as a state and as a trait: results for the whole group $(\mathrm{N}=893)$, for girls $(\mathrm{N}=468)$, and for boys $(\mathrm{N}=425)$

\begin{tabular}{|c|c|c|c|c|c|c|}
\hline Respondents & Variable & Beta & B & $\begin{array}{c}\text { Standard } \\
\text { error B }\end{array}$ & $\mathbf{t}$ & $\begin{array}{c}\text { Level } \\
\mathbf{p}<\end{array}$ \\
\hline Total & $\begin{array}{l}\text { Threat-state } \\
\text { Free trem }\end{array}$ & .11 & $\begin{array}{l}.08 \\
4.00 \\
\end{array}$ & $\begin{array}{l}.02 \\
.30 \\
\end{array}$ & $\begin{array}{c}3.33 \\
13.45 \\
\end{array}$ & $\begin{array}{c}.0009 \\
.0000001 \\
\end{array}$ \\
\hline \multicolumn{7}{|c|}{$\begin{array}{l}\text { Coefficient of multiple correlation: } \mathrm{R}=.11 \\
\text { Adjusted coefficient of multiple determination: } \mathrm{R}^{2}=.01 \\
\text { Significance of the equation: } \mathrm{F}(1,891)=11.09 ; \mathrm{p}<.0009 \\
\text { Standard error of estimation: } 4.62\end{array}$} \\
\hline Girls & $\begin{array}{l}\text { Threat-state } \\
\text { Free trem }\end{array}$ & .11 & $\begin{array}{c}.08 \\
3.62\end{array}$ & $\begin{array}{l}.03 \\
.41\end{array}$ & $\begin{array}{l}2.44 \\
8.85\end{array}$ & $\begin{array}{c}.02 \\
.0000001\end{array}$ \\
\hline \multicolumn{7}{|c|}{$\begin{array}{l}\text { Coefficient of multiple correlation: } \mathrm{R}=.11 \\
\text { Adjusted coefficient of multiple determination: } \mathrm{R}^{2}=.01 \\
\text { Significance of the equation: } \mathrm{F}(1,466)=5.96 ; \mathrm{p}<.02 \\
\text { Standard error of estimation: } 4.62\end{array}$} \\
\hline Boys & $\begin{array}{l}\text { Self-esteem } \\
\text { Free trem }\end{array}$ & -.17 & $\begin{array}{c}-.18 \\
10.68\end{array}$ & $\begin{array}{l}.05 \\
1.57\end{array}$ & $\begin{array}{c}-3.49 \\
6.80\end{array}$ & $\begin{array}{c}.0005 \\
.0000001\end{array}$ \\
\hline \multicolumn{7}{|c|}{$\begin{array}{l}\text { Coefficient of multiple correlation: } \mathrm{R}=.17 \\
\text { Adjusted coefficient of multiple determination: } \mathrm{R}^{2}=.03 \\
\text { Significance of the equation: } \mathrm{F}(1,423)=12.16 ; \mathrm{p}<.0005 \\
\text { Standard error of estimation: } 4.56\end{array}$} \\
\hline
\end{tabular}

influence of the mentioned variable is weak. The variable explains $1 \%$ of the dependent variable variation (adjusted $\mathrm{R}^{2}=.01 ; \mathrm{F}(1,891)=11.09$; $\mathrm{p}<.0009)$. The remaining variables included in the research turned out to be irrelevant determinants of the strategy of aggression used in a group of adolescents. The beta value indicates that the higher the level of the situational conflict appraisal as a threat, the higher the level of the strategy of aggressive coping used by adolescents in a social conflict situation.

Separate analyses for groups distinguished by gender were carried out (cf. Table 1). Stepwise analysis of regression indicated that out of seven independent variables introduced to the regression model, one was significant in explaining the use of the strategy of aggressive coping in girls in a social conflict situation. The remaining variables included in the research turned out to be irrelevant determinants of the use of the strategy of aggression in girls. The calculations prove that an important determining role for the girls' strategy of aggressive coping is played by the situational appraisal of a conflict as a threat. The coefficient of multiple correlation is $\mathrm{R}=.11$ and it indicates that the linear correlation between the strategy of aggressive coping used by girls in a social conflict situation and the total influence of the mentioned variable is weak. Only $1 \%$ of the dependent variable variation is explained by the independent variable (adjusted $\mathrm{R}^{2}=.01, \mathrm{~F}(1,466)=5.96$; $\mathrm{p}<.02)$. The parameter of regression equation including its relevance proves that the higher the level of the situational appraisal of a conflict as a threat, the higher the level of the strategy of aggressive coping used by girls in a social conflict situation.

It has further been examined, what set of personality variables influences the level of the use of strategies of aggressive coping in boys in a social conflict situation. One independent variable turned out to be significant in the regression equation, namely, self-esteem. The coefficient of multiple correlation is $\mathrm{R}=.17$ and it indicates that the linear correlation between the strategy of aggressive coping used by boys in a social conflict situation and the total 
influence of the mentioned variable is weak. The value of the adjusted $\mathrm{R}^{2}=.03(\mathrm{~F}(1,423)$ $=12.16 ; \mathrm{p}<.0005)$ and it indicates that $3 \%$ of the variability with regard to the strategy of aggressive coping employed by boys in a conflict situation is explained by the influence of the accepted independent variable. The remaining variables included in the research turned out to be irrelevant determinants of the strategy of aggression used in the group of boys. Beta value proves that the lower the level of self-esteem, the higher the level of the strategy of aggressive coping used by boys in a social conflict situation.

The analysis of the empirical data performed so far was centred on the strategy of aggressive coping employed by adolescents in a social conflict situation. There remains the question of what set of personality variables shall prove to be relevant for the whole group of the respondents, and for both groups distinguished by gender, with regard to the use of the strategy of avoiding coping. The results of the following regression analysis, shown in Table 2, provide the answer.

Out of seven personality variables in the regression equation, the significant influence on the strategies of avoiding coping used by adolescents in a social conflict situation is exerted by the dispositional appraisal of a conflict as a harm/loss, the dispositional appraisal of a conflict as a challenge and self-esteem. The coefficient of multiple correlation is $\mathrm{R}=.16$ and it indicates that the linear correlation between the strategy of avoiding coping employed by adolescents in a social conflict situation and the total influence of the mentioned variables

Table 2. Stepwise multiple regression for the results of the Avoidance (A) scale of the CSCS against self-esteem of the Self-Esteem Scale (SES) and cognitive appraisal of the Stress Appraisal Questionnaire (SAQ) as a state and as a trait: results for the whole group $(\mathrm{N}=893)$, for girls $(\mathrm{N}=468)$, and for boys $(\mathrm{N}=425)$

\begin{tabular}{|c|c|c|c|c|c|c|}
\hline Respondents & Variable & Beta & B & $\begin{array}{c}\text { Standard } \\
\text { error B }\end{array}$ & $\mathbf{t}$ & $\begin{array}{c}\text { Level } \\
\mathbf{p}<\end{array}$ \\
\hline Total & $\begin{array}{l}\text { Harm/loss- } \\
\text {-trait } \\
\text { Challenge- } \\
\text {-trait } \\
\text { Self-esteem } \\
\text { Free trem } \\
\end{array}$ & $\begin{array}{r}.12 \\
-.08 \\
-.08\end{array}$ & $\begin{array}{r}.15 \\
-.07 \\
-.06 \\
4.42\end{array}$ & $\begin{array}{l}.04 \\
.03 \\
.03 \\
.85\end{array}$ & $\begin{array}{c}3.52 \\
-2.25 \\
-2.49 \\
5.17\end{array}$ & $\begin{array}{c}.0005 \\
.03 \\
.01 \\
.0000001\end{array}$ \\
\hline \multicolumn{7}{|c|}{$\begin{array}{l}\text { Coefficient of multiple correlation: } \mathrm{R}=.16 \\
\text { Adjusted coefficient of multiple determination: } \mathrm{R}^{2}=.03 \\
\text { Significance of the equation: } \mathrm{F}(3,889)=8.17 ; \mathrm{p}<.00002 \\
\text { Standard error of estimation: } 3.42\end{array}$} \\
\hline Girls & $\begin{array}{l}\text { Harm/loss- } \\
\text {-trait } \\
\text { Free trem } \\
\end{array}$ & .15 & $\begin{array}{c}.18 \\
2.80\end{array}$ & $\begin{array}{l}.06 \\
.35\end{array}$ & $\begin{array}{l}3.20 \\
8.07\end{array}$ & $\begin{array}{c}.002 \\
.0000001\end{array}$ \\
\hline \multicolumn{7}{|c|}{$\begin{array}{l}\text { Coefficient of multiple correlation: } \mathrm{R}=.15 \\
\text { Adjusted coefficient of multiple determination: } \mathrm{R}^{2}=.02 \\
\text { Significance of the equation: } \mathrm{F}(1,466)=1.23 ; \mathrm{p}<.002 \\
\text { Standard error of estimation: } 3.37\end{array}$} \\
\hline Boys & $\begin{array}{l}\text { Harm/Loss- } \\
\text {-state } \\
\text { Self-esteem } \\
\text { Free trem }\end{array}$ & $\begin{array}{c}.10 \\
-.20\end{array}$ & $\begin{array}{r}.12 \\
-.17 \\
8.32\end{array}$ & $\begin{array}{l}.06 \\
.04 \\
1.24\end{array}$ & $\begin{array}{c}2.11 \\
-4.29 \\
6.72\end{array}$ & $\begin{array}{c}.04 \\
.00002 \\
.0000001\end{array}$ \\
\hline \multicolumn{7}{|c|}{$\begin{array}{l}\text { Coefficient of multiple correlation: } \mathrm{R}=.23 \\
\text { Adjusted coefficient of multiple determination: } \mathrm{R}^{2}=.05 \\
\text { Significance of the equation: } \mathrm{F}(2,422)=11.77 ; \mathrm{p}<.00001 \\
\text { Standard error of estimation: } 3.44\end{array}$} \\
\hline
\end{tabular}


is weak. The adjusted coefficient of multiple determination is $3 \%$ and it indicates that the included group of independent variables explains only a part of the dependent variable (adjusted $\left.\mathrm{R}^{2}=.03 ; \mathrm{F}(3,889)=8.17 ; \mathrm{p}<.00002\right)$. Beta values prove that the higher the level of the dispositional appraisal of a conflict as a harm/ loss, and lower the level of the dispositional appraisal of a conflict as a challenge and lower level of self-esteem, the higher the level of the strategy of avoiding coping used by adolescents in a social conflict situation.

Will the same variables turn out to be relevant for girls? To find out, separate analyses for groups distinguished by gender (Table 2) were carried out. Only one personality variable turned out to be relevant in the regression equation. The dispositional appraisal of a conflict as a harm/loss influences the level of the strategy of avoiding coping employed by girls. The coefficient of multiple correlation is $\mathrm{R}=.15$ and it indicates that the linear correlation between the strategy of avoiding coping used by girls in a social conflict situation and the total influence of the mentioned variable is weak. The adjusted coefficient of multiple determination is rather low (adjusted $\mathrm{R}^{2}=.02$ ) which suggests that only $2 \%$ of the variability of avoiding coping employed by girls in a social conflict was explained by the influence of the accepted independent variable $(\mathrm{F}(1,466)=10.27 ; \mathrm{p}<.003)$. The remaining independent variables included in the research turned out to be irrelevant determinants of the use of the strategy of avoidance in the group of girls. Beta value indicates that the higher the level of the dispositional appraisal of a conflict as a harm/loss, the higher the level of the strategy of avoiding coping used by girls in a social conflict situation.

What set of personality variables shall turn out to be relevant for boys? The results of another regression analysis, shown in Table 2, provide the answer to the question. Out of seven variables, only two turned out to be relevant in the regression equation. They are the situational appraisal of a conflict as a harm/loss and selfesteem. The coefficient of multiple correlation is $\mathrm{R}=.23$ and it indicates that the linear correlation between the strategy of avoiding coping used by boys in a social conflict situation and the total influence of the mentioned variables is low. The value of the adjusted $\mathrm{R}^{2}=.05$ and it indicates that $5 \%$ of the dependent variable, which is the strategy of avoiding coping used by boys, is explained by these variables $(\mathrm{F}(2,422)$ $=11.77 ; \mathrm{p}<.00001)$. Beta values prove that the higher the level of the situational appraisal of a conflict as a harm/loss and lower the level of self-esteem, the higher the level of the strategy of avoiding coping used by boys in a social conflict situation.

The model of multiple regression for the strategy of submissive coping in a social conflict situation as an explained variable is shown in Table 3.

The results indicate that the situational appraisal of a conflict as a harm/loss has a significant influence on the strategy of submission employed by adolescents (the whole group) in a social conflict situation. The coefficient of multiple correlation is $\mathrm{R}=.07$ and it indicates that the linear correlation between the strategy of submissive coping used by adolescents in a social conflict situation and the total influence of the mentioned variable is weak. The explained variation for the strategy of submission used by adolescents is $0.5 \%$ (adjusted $\mathrm{R}^{2}=.005$; $\mathrm{F}(1,891)=449 ; \mathrm{p}<.03)$. The remaining independent variables included in the research turned out to be irrelevant determinants of the strategy of submission in a group of youth. Beta value indicates that the higher the level of the situational appraisal of a conflict as a harm/loss, the higher the level of the strategy of submissive coping used by adolescents in a social conflict situation.

Will the same set of personality variables turn out to be relevant for girls and boys, who more often employ the submissive coping strategy in a social conflict situation? The results of another regression analysis, shown in Table 3, provide the answer to the question.

The stepwise analysis of regression indicated that out of the variables introduced to the regression model, two were significant in explaining the strategy of submissive coping used by girls in a social conflict situation; the situational appraisal of a conflict as a threat and self-esteem. 
Table 3. Stepwise multiple regression for the results of the Submission scale (S) of the CSCS against self-esteem of the Self-Esteem Scale (SES) and cognitive appraisal of the Stress Appraisal Questionnaire (SAQ) as a state and as a trait: results for the whole group $(\mathrm{N}=893)$, for girls $(\mathrm{N}=468)$, and for boys $(\mathrm{N}=425)$

\begin{tabular}{|c|c|c|c|c|c|c|}
\hline Respondents & Variable & Beta & B & $\begin{array}{c}\text { Standard } \\
\text { error B }\end{array}$ & $t$ & $\begin{array}{c}\text { Level } \\
\mathbf{p}<\end{array}$ \\
\hline Total & $\begin{array}{l}\text { Harm/Loss- } \\
\text { state } \\
\text { Free trem }\end{array}$ & -.07 & $\begin{array}{l}-.10 \\
7.65\end{array}$ & $\begin{array}{l}.05 \\
.32\end{array}$ & $\begin{array}{l}-2.12 \\
23.70\end{array}$ & $\begin{array}{c}.03 \\
.0000001\end{array}$ \\
\hline \multicolumn{7}{|c|}{$\begin{array}{l}\text { Coefficient of multiple correlation: } \mathrm{R}=.07 \\
\text { Adjusted coefficient of multiple determination: } \mathrm{R}^{2}=.005 \\
\text { Significance of the equation: } \mathrm{F}(1,891)=4.49 ; \mathrm{p}<.03 \\
\text { Standard error of estimation: } 4.46\end{array}$} \\
\hline Girls & $\begin{array}{l}\text { Threat-state } \\
\text { Self-esteem } \\
\text { Free trem }\end{array}$ & $\begin{array}{l}-.10 \\
-.11\end{array}$ & $\begin{array}{l}-.07 \\
-.10 \\
1.38 \\
\end{array}$ & $\begin{array}{l}.03 \\
.04 \\
1.37 \\
\end{array}$ & $\begin{array}{l}-2.13 \\
-2.37 \\
7.59 \\
\end{array}$ & $\begin{array}{c}.03 \\
.02 \\
.0000001 \\
\end{array}$ \\
\hline \multicolumn{7}{|c|}{$\begin{array}{l}\text { Coefficient of multiple correlation: } \mathrm{R}=.14 \\
\text { Adjusted coefficient of multiple determination: } \mathrm{R}^{2}=.02 \\
\text { Significance of the equation: } \mathrm{F}(2,465)=4.41 ; \mathrm{p}<.01 \\
\text { Standard error of estimation: } 4.40\end{array}$} \\
\hline Boys & $\begin{array}{l}\text { Challenge- } \\
\text {-trait Free } \\
\text { trem }\end{array}$ & -.13 & $\begin{array}{r}-.15 \\
8.60\end{array}$ & $\begin{array}{l}.06 \\
.48\end{array}$ & $\begin{array}{r}-2.70 \\
17.89\end{array}$ & $\begin{array}{c}.007 \\
.0000001\end{array}$ \\
\hline \multicolumn{7}{|c|}{$\begin{array}{l}\text { Coefficient of multiple correlation: } \mathrm{R}=.13 \\
\text { Adjusted coefficient of multiple determination: } \mathrm{R}^{2}=.02 \\
\text { Significance of the equation: } \mathrm{F}(1,423)=7.28 ; \mathrm{p}<.007 \\
\text { Standard error of estimation: } 4.46\end{array}$} \\
\hline
\end{tabular}

The coefficient of multiple correlation is $\mathrm{R}=$ .14 and it indicates that the linear correlation between the strategy of submissive coping used by girls in a social conflict situation and the total influence of the mentioned variables is weak. Totally, these variables explain $2 \%$ of the variability of the results obtained by girls on the $\mathrm{S}$ scale of the CSCS questionnaire (adjusted $\mathrm{R}^{2}$ $=.02 ; \mathrm{F}(2,465)=4.41 ; \mathrm{p}<.01)$. The remaining independent variables included in the research turned out to be irrelevant determinants of the strategy of submission used by girls. Beta values indicate that the lower the level of the situational appraisal of a conflict as a threat and lower level of self-esteem, the more often the girls use the strategy of submissive coping in a social conflict situation.

Whereas, the parameter of regression equation, including its relevance, proves that the dispositional, cognitive appraisal of a conflict as a challenge substantially influences the level of the strategy of submissive coping in a social conflict situation used in the group of boys (cf. Table 3). The coefficient of multiple correlation is $\mathrm{R}=.13$ and it indicates that the linear correlation between the strategy of submissive coping used by boys in a social conflict situation and the total influence of the mentioned variable is weak. The value of the adjusted $\mathrm{R}^{2}=.02$ and it indicates that $2 \%$ of the dependent variable which is the strategy of submissive coping employed by boys is explained by the variable $(\mathrm{F}(1,423)$ $=7.28 ; \mathrm{p}<.007)$. The parameter of regression equation, including its relevance, proves that the lower the level of the dispositional appraisal of a conflict as a challenge, the higher the level of the strategy of submissive coping applied by boys in a social conflict situation.

In further analyses the dependent variable was the strategy of task-oriented coping used by adolescents in a social conflict. The results of multiple regression for the whole group as well as for groups distinguished by gender are illustrated in Table 4. 
Table 4. Stepwise multiple regression for the results of the Task-oriented (T) scale of the CSCS questionnaire against self-esteem of the Self-Esteem Scale (SES) and cognitive appraisal of the Stress Appraisal Questionnaire (SAQ) as a state and as a trait: results for the whole group $(\mathrm{N}=893)$, for girls $(\mathrm{N}=468)$, and for boys $(\mathrm{N}=425)$

\begin{tabular}{|c|c|c|c|c|c|c|}
\hline Respondents & Variable & Beta & B & $\begin{array}{c}\text { Standard } \\
\text { error B }\end{array}$ & $t$ & $\begin{array}{c}\text { Level } \\
\text { p }<\end{array}$ \\
\hline Total & $\begin{array}{l}\text { Threat-state } \\
\text { Self-esteem } \\
\text { Free trem } \\
\end{array}$ & $\begin{array}{c}-.09 \\
.09\end{array}$ & $\begin{array}{c}-.09 \\
.12 \\
14.54 \\
\end{array}$ & $\begin{array}{l}.03 \\
.05 \\
1.51\end{array}$ & $\begin{array}{l}-2.73 \\
2.59 \\
9.61\end{array}$ & $\begin{array}{c}.006 \\
.01 \\
.0000001\end{array}$ \\
\hline \multicolumn{7}{|c|}{$\begin{array}{l}\text { Coefficient of multiple correlation: } \mathrm{R}=.13 \\
\text { Adjusted coefficient of multiple determination: } \mathrm{R}^{2}=.02 \\
\text { Significance of the equation: } \mathrm{F}(2,890)=8,14 ; \mathrm{p}<.0003 \\
\text { Standard error of estimation: } 6.42\end{array}$} \\
\hline Girls & $\begin{array}{l}\text { Threat-state } \\
\text { Free trem }\end{array}$ & -.09 & $\begin{array}{c}-.09 \\
19.03\end{array}$ & $\begin{array}{l}.04 \\
.56\end{array}$ & $\begin{array}{l}-2.02 \\
34.08\end{array}$ & $\begin{array}{c}.04 \\
.0000001\end{array}$ \\
\hline \multicolumn{7}{|c|}{$\begin{array}{l}\text { Coefficient of multiple correlation: } \mathrm{R}=.09 \\
\text { Adjusted coefficient of multiple determination: } \mathrm{R}^{2}=.009 \\
\text { Significance of the equation: } \mathrm{F}(1,466)=4.08 ; \mathrm{p}<.04 \\
\text { Standard error of estimation: } 6.31\end{array}$} \\
\hline Boys & $\begin{array}{l}\text { Self-esteem } \\
\text { Free trem }\end{array}$ & .21 & $\begin{array}{l}.32 \\
6.74\end{array}$ & $\begin{array}{c}.07 \\
2.19\end{array}$ & $\begin{array}{l}4.40 \\
3.08\end{array}$ & $\begin{array}{c}.00001 \\
.002\end{array}$ \\
\hline \multicolumn{7}{|c|}{$\begin{array}{l}\text { Coefficient of multiple correlation: } \mathrm{R}=.21 \\
\text { Adjusted coefficient of multiple determination: } \mathrm{R}^{2}=.04 \\
\text { Significance of the equation: } \mathrm{F}(1,423)=19.35 ; \mathrm{p}<.00001 \\
\text { Standard error of estimation: } 6.37\end{array}$} \\
\hline
\end{tabular}

The situational appraisal of a conflict as a threat and self-esteem are the determinants of the task-oriented strategy of coping used by adolescents (the whole group) in a social conflict situation. The remaining independent variables included in the research turned out to be irrelevant determinants of the task-oriented strategy used by adolescents in a social conflict situation. The coefficient of multiple correlation is $\mathrm{R}=.13$ and it indicates that the linear correlation between the task-oriented strategy of coping used by adolescents in a social conflict situation and the total influence of the mentioned variables is weak. The value of the adjusted $\mathrm{R}^{2}=$ .02 and it indicates that $2 \%$ of the $\mathrm{T}$ dependent variable variation in the group of adolescents was explained by the influence of the accepted set of independent variables $(\mathrm{F}(2,890)=8.14$; $\mathrm{p}<.0003)$. Beta values prove that the lower the level of the situational appraisal of a conflict as a threat and higher the level of self-esteem, the higher the level of the task-oriented strategy of coping used by adolescents in a social conflict situation.
What influence on the level of task-oriented strategy employed by girls and boys will a set of personality variables exert? The results of another regression analysis, shown in Table 4, provide the answer to the question.

The stepwise analysis of regression indicated that out of the variables introduced to the regression model, one was significant in explaining the task-oriented strategy of coping used by girls in a social conflict situation: the situational appraisal of a conflict as a threat. The coefficient of multiple correlation is $\mathrm{R}=$ .09 and it indicates that the linear correlation between the task-oriented strategy of coping used by girls in a social conflict situation and the total influence of the mentioned variables is weak. Totally, the independent variable explains the $.9 \%$ of the variability of the results obtained by the girls in the T scale of the CSCS questionnaire $(\mathrm{F}(1,466)=4.08 ; \mathrm{p}<.04)$. The remaining independent variables included in the research turned out to be irrelevant determinants of the task-oriented strategy used by girls. Beta value indicates that the lower the level of the 
situational appraisal of a conflict as a threat, the more often the girls use the task-oriented strategy of coping in a social conflict situation.

Self-esteem plays an important role in conditioning the task-oriented strategy used by boys in a social conflict situation. Beta value indicates that the higher the level of self-esteem, the more often boys use the task-oriented strategy of coping in a social conflict situation. The coefficient of multiple correlation is $\mathrm{R}=.21$ and it indicates that the linear correlation between the task-oriented strategy of coping employed by boys in a social conflict situation and the total influence of the mentioned variables is low. The coefficient of multiple determination adjusted for the task-oriented strategy used by boys in a social conflict situation is $4 \%$ and it proves that the set of variables explains a part of dependent variable variation $(\mathrm{F}(1,423)=$ 19.39; $\mathrm{p}<.00001)$.

In the light of the performed statistical verification, one may claim that the obtained results allowed to verify partially the relevance of the hypothesis H.1 presented in the methodological part of the work.

\section{DISCUSSION}

Self-esteem influences the interpersonal relationships as well as the choice of behaviour in difficult situations. It turns out that the lower the level of self-esteem in an adolescent, the more often they employ aggressive strategies of coping in a social conflict situation. It is also worth pointing out that the level of self-esteem seems to play a greater role in case of aggressive strategies applied by boys than by girls. It means that boys have social consent to express direct aggression, which is unacceptable in the case of girls (Ranschburg, 1993). These differences are culturally conditioned and they are further connected with the specificity of the socio-emotional development of girls and boys (Salmivalli and Kaukiainen, 2004; Borecka-Biernat, 2006; Batool, 2013). People with low self-esteem are oversensitive, suspicious, withdrawn from social relationship and their existing relationships with the environment are of a conflicted natu- re (Donnellan et al., 2005; Sandstrom, Herlan, 2007; Diamantopoulou, Rydell, Henricsson, 2008; Eftimie, Ionescu, 2010). Such a situation is undoubtedly connected with the fact that those people experience numerous internal conflicts, which in turn determines the presence of strong negative emotions and acting-out behaviours. Therefore, adolescents with low self-esteem tend to have unsatisfactory and confrontational relationships with peers.

Cognitive attitude of a young person to a social conflict situation may influence the choice of a remedial strategy. The research results analysis revealed that the situational appraisal of a conflict as a threat ties with the strategy of aggressive coping in a social conflict situation. One may assume that experiencing threat favours generating resentment and aggressive attitudes towards others. This tendency seems to be compatible with Leonard Berkowitz's (1992) claim that aggression arises in a man as a result of threat perception or as a result of an assumption that one is the target of intentional, inappropriate treatment and from the violation of one's value. Similar results were obtained by Kowalski et al. (2005), Dorota Włodarczyk and Kazimierz Wrześniewski (2010). These researchers revealed that a person who appraises a difficult situation as a threat uses such remedial actions which shall free them (even for a short period of time) from the feeling of threat - the unpleasant state. In the repertoire of such strategies, an individual has the ones, which concentrate on the reduction of unpleasant emotions, not on the solution of the problem. Within the emotion-focused strategy an individual actively fights a difficult situation in order to overcome it. Aggression as a strategy is a form of irrational (emotional) behaviour and a sign of the lack of the ability to cope with difficult situations frequently encountered by an adolescent (Kossewska, 2008). Therefore, adolescents with higher intensification of the appraisal of a conflict in school and out-of-school environment as a threat, show aggression in their behaviour, taking the form of a physical and/or verbal attack directed towards other people.

The presented research results indicate that low self-esteem, low assessment of both one's 
capabilities and the effectiveness of one's actions, favour the appearance of avoiding forms of behaviour, which reduce the emotional strain resulting from the conflict inherent to the experienced difficulties (Campbell, Lavallee, 1993; Martowska, 2012). As we may notice, the negative attitude to oneself and the feeling of doubt in one's power, both favour withdrawing from interaction, avoiding relationship with others, not undertaking action, expressing the lack of trust and hostile social attitude. The aversion towards other people and the inability to overcome the social barrier lead to many conflicts with the environment. On the other hand, low self-esteem is connected with low activity, lack of involvement in the solution of problems, as well as fear and reluctance to participate in interpersonal contacts. Therefore, low self-esteem is the indicator of a withdrawal from acting and lack of desire to pursue goals in a difficult situation. A young person with an avoiding behaviour strategy in a conflict situation, engages in replacement activities protecting the $m e$ (an escape from the problem) and/or looks for social contacts, however, such a person does not attempt to solve the conflict.

A significant factor determining the choice of behaviour in a conflict is the way it is perceived (Reykowski, 2002). In the research, it was claimed that adolescents using avoiding strategies in a social conflict situation are distinguished by a higher situational and dispositional appraisal of a conflict as a harm/loss. As we can see, this strategy is actually a decision on whether it is worth getting involved in a conflict or not. The possible profits and losses are assessed while making the decision (Antonini, 1998). The decision is favoured in a situation, when the costs or the risk of engaging in a conflict are great and the possible profits are insufficient. The moment a young person notices that the partner's activity has led to some harm connected, for example, with self-esteem, s/he is willing to withdraw from the conflict situation. This may be explained by the obtained connections between the strategy and the appraisal of a conflict as a harm/loss, when an individual has nothing to gain and is convinced that the situation is irreversible. The escape from the conflict situation leads to giving up the goals of activities as a result of the encountered difficulties. Avoiding the confrontation with a conflict by undertaking some additional activities that focus attention (watching TV, eating, sleeping) or looking for contacts with other people, is a sign of self-defence against the existing harm, having the form of a loss of material properties or personal values such as health, social prestige, a relative, or family. The apparent tendency seems to be compatible with the results obtained by Mark H. Anshel and Bruce Wells (2000), Geneviève Bouchard (2003), Dorota DomińskaWerbel (2014), Mario Mikulincer and Victor Florian (1995), and Dorota Włodarczyk and Kazimierz Wrześniewski (2010).

In the course of the performed analysis, it was claimed that the lower the level of selfesteem, the more often the girls, in particular, use the submissive coping strategies in a social conflict situation. There appears an assumption that girls do not feel confident in the area of their abilities and the effectiveness of the undertaken tasks, which causes greater inclination to submission. An adolescent girl showing submissive behaviour in a conflict situation, gives in, limits herself in the accomplishment of her desires, tolerates the threat of her own interests and refrains from defending her rights and feelings. Submission is an attempt to overcome a sudden conflict, whose consequences may be severe (Wojciszke, 2011). The strategy is classified in the area of passiveness - facilitation (Węgłowska-Rzepa, 2000) and therefore it may reinforce the acceptance and approval of an individual by others (e.g. by agreeing, Cialdini, Goldstein, 2004). By being a part of a particular group, an individual wants to be accepted and liked and in order to achieve these two goals, they need to give in to the group's rules. By doing so, an individual gains approval, the feeling of belonging and sympathy. One may assume that an individual shall use submissive strategies of functioning in a social conflict and adapt to others more often, since doing so is safer for the person's self-esteem.

The analysis of the presented research results indicated that lower tendency to the situational appraisal of a conflict as a threat, as a harm/loss 
and the dispositional appraisal of a conflict as a threat, favours the intensification of the use of submissive strategies of coping in a social conflict situation. A person choosing such a strategy does not perceive the conflict as a threat, their priorities are different. Keeping the relationship becomes the main aim and the person does not perceive any threats to their state in the realisation of their aspiration (Wojciszke, 2011). It is also worth noticing that a lower tendency to appraise a conflict situation as causing damage in the form of a loss of some material or personal values, such as health damages, self-esteem or a relative, is connected with higher tendency to use submissive strategies of coping. One may assume that once the adolescent notices that the activities of an interaction partner may lead to some harm, then they tend to give up their goal to the benefit of the other person's pursuance (Balawajder, 2010). Submission may be perceived as a means to maintain good relationships with a partner, and this aim may turn out to be of greater importance in a particular situation. Moreover, the noticed lower tendency to perceive potential benefits, which may arise from the conflict situation, strengthens the tendency to use submissive strategies of coping. There appears an assumption that if an adolescent believes that there is no chance of benefit, then submission to the partner of the conflict may be a better strategy of coping than engaging in an activity directed against the partner and fighting, as well as being exposed to greater harm. Especially when one realises the insignificance of the goal one strives for (Balawajder, 2010).

The analysis of research results has also revealed that adolescents using task-oriented strategy in a social conflict situation obtained higher results in the level of general self-esteem. Global self-esteem is also defined as self-worth (Kofta, Doliński, 2000). Self-worth generates the readiness to act, to perform, to enter relationships. Individuals with higher level of selfworth are more aware of their abilities and show a tendency to engage in an activity. Starting new relationships is not a problem for them. Adolescents with higher level of self-esteem undertake more efforts to directly solve all the problems they face. They are concentrated on efforts to overcome obstacles, thus, they employ task-oriented strategies to a greater extent. Such people are generally oriented to undertake activities which shall enable them to realise their intentions and goals, therefore, their performance in a conflict situation is based on the assertive dimension (Heimpel, Elliot, Wood, 2006; Martowska, 2012).

The research has also indicated that lower tendency to the situational appraisal of a conflict as a threat favours the intensification of the use of the task-oriented strategy of coping in adolescents in a social conflict situation. It appears that adolescents coping in a task-oriented way do not perceive the conflict situation as threatening with regard to the loss of material properties or a close person. Numerous authors (Lazarus, Folkman, 1984; Mikulincer, Florian, 1995; Pawłów, 1997; Bjorck, Cuthberston, Thurman, Yung, 2001; Domińska-Werbel, 2014) have repeatedly indicated that the perception of a particular situation as a threat makes an individual choose behaviour enabling the reduction of negative emotions, not solving the problem. Once an individual realises that they have the possibility to influence the course of a stressful event, they more often choose the task-oriented strategy directed to the problem. Despite the presence of theoretical and empirical prerequisites, the connections between the situational and dispositional cognitive appraisal of a conflict as a challenge and the task-oriented strategy have not been confirmed. Perhaps, the lack of the expected connections results from the fact that this strategy is both difficult to achieve and rarely noticed (Wojciszke, 2011). The fact that a particular person achieved a high result on the T scale of the CSCS Questionnaire may result from the fact that it is a tool of forced choice, where one needs to pick the preferred option out of four possible answers. Therefore, an individual with a low tendency to use some strategies shall pick the task-oriented strategy, even though they do not use it in everyday life. This is some obvious limitation of tools of this kind.

Generalising the above mentioned results, one may notice that lower appraisal of one's capabilities in adolescents and appraisal of a conflict situation as a threat or as a harm/loss, 
generally co-occur with the tendency to react destructively to a conflict. However, higher selfesteem and not perceiving the conflict as a threat create greater possibilities of constructive struggle with a social conflict situation. Moreover, it needs to be emphasised that the distinguished personality variables are not strong predictors of the destructive (aggression, avoidance, submission) and constructive (task-oriented) strategies of coping employed by adolescents in social conflict situations. Therefore, there may exist many other variables co-determining the level of destructive and constructive strategies of coping employed by adolescents in social conflict situations that have not been included in the research. Taking into account the obtained results, further exploration of this area might be conducted through similar research with regard to the genetic (temperament) nature of an indi- vidual's functioning in a conflict and the influence of the family environment on overcoming burdens and biological determinants towards becoming a person actively coping with a conflict. The suggested further research concerning interpersonal conflicts may be performed by both conducting research in the paradigm of quantity research, making it possible to include in one project a wide range of explored variables, which may allow to examine a huge research sample, or by conducting research in the paradigm of quality research, where the individual contact between the participant and the researcher fits in the humanistic dimension of the world, which might be difficult to explain in statistical dependence language, however, by the participation in the research one may discover the richness of meanings and conclusions arising from them.

\section{REFERENCES}

Anshel M.H., Wells B. (2000), Personal and situational variables that describe coping with acute stress in competitive sport. Journal of Social Psychology, 140(4), 434-450.

Antonini D.(1998), Relationship between the big five personality factors and conflict management styles. International Journal of Conflict Management, 9(4), 336-355.

Balawajder K. (2010), Zachowania uczestników konfliktu interpersonalnego. In: D. Borecka-Biernat (Ed.), Sytuacje konfliktu $w$ środowisku rodzinnym, szkolnym i rówieśniczym. Jak sobie radza z nimi dzieci i młodzież?, 137-179. Warszawa: Difin.

Batool S. (2013), Lack of adequate parenting: A potential risk factor for aggression among adolescents. Pakistan Journal of Psychological Research, 28(2), 217-238.

Baumeister R., Campbell J., Krueger J., Vohs K. (2003), Does high self-esteem cause better performance, interpersonal success, happiness, or healthier lifestyles? Psychological Science in the Public Interest, 4(1), $1-44$.

Bedyńska S., Książek M. (2012), Statystyczny drogowskaz, 3: Praktyczny przewodnik wykorzystania modeli regresji oraz równań strukturalnych. Warszawa: Wydawnictwo Akademickie Sedno.

Berkowitz L. (1992), O powstawaniu i regulowaniu gniewu i agresji. Nowiny Psychologiczne, 1-2, 87-105.

Bjorck J., Cuthberston W., Thurman J., Yung S. (2001), Ethnicity, coping and distress among Korean American, Filipino American and Caucasian Americans. Journal of Social Psychology, 141(4), 421-443.

Borecka-Biernat D. (2006), Strategie radzenia sobie młodzieży w trudnych sytuacjach społecznych. Psychospołeczne uwarunkowania. Wrocław: Wydawnictwo Uniwersytetu Wrocławskiego.

Borecka-Biernat D. (2012), Kwestionariusz strategii radzenia sobie młodzieży w sytuacji konfliktu społecznego. Psychologia Wychowawcza, 1-2, 86-118.

Bouchard G. (2003), Cognitive appraisals, neuroticism, and openness as correlates of coping strategies: An integrative model of adaptation to marital difficulties. Canadian Journal of Behavioural Science, 1(35), 1-12.

Brytek A. (2007), Strategie radzenia sobie ze stresem a zasoby osobiste studentek w Polsce i we Francji. Chowanna, 1, 135-147.

Campbell J., Lavallee L. (1993), Who am I? The role of self-concept confusion in understanding the behavior of people with low self-esteem. Boston, MA: Springer. 
Chandler L. (1986), The stress response scale for children: A manual. Pittsburgh: University of Pittsburgh Press.

Cialdini R., Goldstein N. (2004), Social influence: Compliance and conformity. Annual Review of Psychology, 55, 591-621.

Czerwińska-Jasiewicz M. (2003), Społeczno-kulturowe podejście do dorastania. In: A. Jurkowski (Ed.), Z zagadnień współczesnej psychologii wychowawczej, 208-226. Warszawa: Wydawnictwo Instytutu Psychologii PAN.

Deutsch M. (2005), Współpraca i rywalizacja. In: M. Deutsch, T. Coleman (Eds.), Rozwiązywanie konfliktów. Teoria i praktyka, 21-40. Kraków: Wydawnictwo Uniwersytetu Jagiellońskiego.

Diamantopoulou S., Rydell A.-M., Henricsson L. (2008), Can both low and high self-esteem be related to aggression in children? Social Development, 17, 682-698.

Domińska-Werbel D. (2014), Psychologiczne uwarunkowania strategii radzenia sobie młodzieży gimnazjalnej w trudnych sytuacjach społecznych. Legnica: Wydawnictwo Państwowej Wyższej Szkoły Zawodowej im. Witelona.

Donaldson D., Prinstein M.J., Danovsky M., Spirito A. (2000), Patterns of children's coping with life stress. American Journal of Orthopsychiatry, 70(3), 351-359.

Donnellan P.B., Trzesniewski K., Robins R., Moffitt T.E., Caspi A. (2005), Low self-esteem is related to aggression, antisocial behavior, and delinquency. Psychological Science, 16(4), 328-335.

Eftimie S., Ionescu S. (2010), Self esteem on aggressive adolescents. Buletinul UniversităŃii Petrol - Gaze din Ploiesti, Seria StiinŃele EducaŃiei, 62(2), 146-153.

Gregg A. (2003), Optimally conceptualizing implicit self-esteem. Psychological Inquiry, 14(1), 35-38.

Gurba E. (2013), Nieporozumienia z dorastającymi dziećmi w rodzinie. Kraków: Wydawnictwo Uniwersytetu Jagiellońskiego.

Harwas-Napierała B., Trempała J. (2000), Psychologia rozwoju człowieka, vol. 2. Warszawa: Wydawnictwo Naukowe PWN.

Heimpel S., Elliot A., Wood J. (2006), Basic personality dispositions, self-esteem, and personal goals: An approach-avoidance analysis. Journal of Personality, 74, 1293-1319.

Heszen-Niejodek I. (2002), Emocje, ocena poznawcza i strategie w procesie radzenia sobie. In: I. Heszen-Niejodek (Ed.), Teoretyczne i kliniczne problemy radzenia sobie ze stresem, 174-197. Poznań: Stowarzyszenie Psychologia i Architektura.

Kłusek-Wojciszke B. (2009), Kwestionariusz stylów rozwiązywania konfliktów. Czasopismo Psychologiczne, 15(1), 119-140.

Kobus K., Reyes O. (2000), A descriptive study of urban Mexican American adolescents' perceived stress and coping. Hispanic Journal of Behavioral Sciences, 22(2), 163-178.

Kofta M., Doliński D. (2000), Poznawcze podejście do osobowości. In: J. Strelau (Ed.), Psychologia. Podręcznik akademicki. Psychologia ogólna, vol. 2, 561-600. Gdańsk: Gdańskie Wydawnictwo Psychologiczne.

Kossewska J. (2008), Zasoby osobowe a agresja interpersonalna u młodzieży gimnazjalnej. In: H. Wrona-Polańska (Ed.), Zdrowie - stres - choroba w wymiarze psychologicznym, 145-159. Kraków: Oficyna Wydawnicza Impuls.

Kowalski K., Crocker P., Hoar S. (2005), Adolescents' control beliefs and coping with stress in sport. International Journal of Sport Psychology, 36(4), 257-272.

Kulas H. (1986), Samoocena młodzieży. Warszawa: Wydawnictwa Szkolne i Pedagogiczne.

Kurtek P. (2012), Regulacyjna rola idealnego obrazu siebie w radzeniu sobie młodzieży z niepełnosprawnością intelektualną lekkiego stopnia w sytuacjach trudnych. In: Z. Palak, D. Chimicz, A. Pawlak (Eds.), Wielość obszarów we wspótczesnej pedagogice specjalnej, 145-159. Lublin: Wydawnictwo UMCS.

Łaguna M., Lachowicz-Tabaczek K., Dzwonkowska I. (2007), Skala samooceny SES Morrisa Rosenberga polska adaptacja metody. Psychologia Społeczna, 2, 164-176.

Lazarus R., Folkman S. (1984), Stress appraisal and coping. New York: Springer.

Lohman B., Jarvis P. (2000), Adolescent stressors, coping strategies, and psychological health studied in the family context. Journal of Youth and Adolescence, 29, 15-43.

Martowska K. (2012), Psychologiczne uwarunkowania kompetencji społecznych. Warszawa: Liberi Libri.

Mikulincer M., Florian V. (1995), Appraisal of and coping with real-life stressful situation: The contribution of attachment styles. Personality and Social Psychology Bulletin, 21(4), 406-415. 
Ogińska-Bulik N. (2001), Zasoby osobiste jako wyznaczniki radzenia sobie ze stresem. Acta Universitatis Lodziensis Folia Psychologica, 5, 83-93.

Ostrowsky M.K. (2010), Are violent people more likely to have low self-esteem or high self-esteem? Aggression and Violent Behavior, 15, 69-75.

Pawłów E. (1997), Twórcze strategie radzenia sobie z problemami życiowymi. Zeszyty Naukowe Uniwersytetu Szczecińskiego. Psyche, 1, 204, 201-212.

Perez M., Vohs K., Joiner J., Thomas E. (2005), Discrepancies between self- and other-esteem as correlates of aggression. Journal of Social \& Clinical Psychology, 24, 607-620.

Pisula E., Sikora R. (2008), Wiek i płeć a radzenie sobie ze stresem przez młodzież w wieku 12-17 lat. Przegląd Psychologiczny, 4, 405-422.

Polak K. (2010), Uczeń w sytuacji konfliktów szkolnych. In: D. Borecka-Biernat (Ed.), Sytuacje konfliktowe w środowisku rodzinnym, szkolnym i rówieśniczym, 23-40. Warszawa: Difin.

Ranschburg J. (1993), Lęk, gniew, agresja, trans. M. Schweinitz-Kulisiewicz. Warszawa: Wydawnictwa Szkolne i Pedagogiczne.

Reykowski J. (2002), Psychological meaning of democracy and resolving the social coordination problems. Polish Psychological Bulletin, 4, 19-30.

Rosenberg M. (1965), Society and the adolescent self-image. Princeton, NJ: Princeton University Press.

Różańska-Kowal J. (2004), Szkoła jako główne źródło stresu młodzieży w wieku dorastania. Kwartalnik Pedagogiczny, 3, 203-214.

Salmivalli Ch., Kaukiainen A. (2004), "Female aggression" revisited: Variable- and person-centered approaches to studying gender differences in different types of aggression. Aggressive Behaviour, 30, 158-163.

Sandstrom M., Herlan R. (2007), Threatened egotism or confirmed inadequacy? How children's perceptions of social status influence aggressive behavior toward peers. Journal of Social \& Clinical Psychology, 26, 272-299.

Smetana J., Daddis C. (2002), Domain-specific antecedents of psychological control, parental monitoring, and adolescent autonomy: The role of parenting beliefs and practices. Child Development, 73, 563-580.

Szpitalak M., Polczyk R. (2015), Samoocena. Geneza, struktura, funkcje i metody pomiaru. Kraków: Wydawnictwo Uniwersytetu Jagiellońskiego.

Tomaszewski T. (1984), Ślady i wzorce. Warszawa: Wydawnictwa Szkolne i Pedagogiczne.

Tyszkowa M. (1986), Zachowanie się dzieci w sytuacjach trudnych. Warszawa: Państwowe Wydawnictwo Naukowe.

Węgłowska-Rzepa K. (2000), Style funkcjonowania młodzieży w grupie społecznej. In: D. Borecka-Biernat, K. Węgłowska-Rzepa (Eds.), Zachowanie młodzieży w sytuacji kontaktu społecznego, 101-196. Wrocław: Wydawnictwo Uniwersytetu Wrocławskiego.

Williams K., McGillicuddy-DeLisi A. (2000), Coping strategies in adolescents. Journal of Applied Developmental Psychology, 20, 537-549.

Wilmot W., Hocker J. (2011), Konflikty między ludźmi, thum. M. Höffner. Warszawa: Wydawnictwo Naukowe PWN.

Włodarczyk D., Wrześniewski K (2005), Ocena stresu w kategoriach wyzwania u chorych po zawale sercapróba syntezy na podstawie danych empirycznych. Przeglad Psychologiczny, 4, 339-358.

Włodarczyk D., Wrześniewski K. (2010), Kwestionariusz Oceny Stresu (KOS). Przegląd Psychologiczny, 4, 479-496.

Wojciszke B. (2011), Psychologia społeczna. Warszawa: Wydawnictwo Naukowe Scholar. 